\title{
SYSTEM FOR REAL TIME SUPPORT IN CONSTRUCTION MATERIALS SELECTION
}

\author{
Edmundas Kazimieras ZAVADSKAS ${ }^{1}$, Artūras KAKLAUSKAS ${ }^{2}$, Audrius BANAITIS ${ }^{2}$ \\ and Vaidotas TRINKŪNAS ${ }^{2}$
}

${ }^{1}$ Department of Construction Technology and Management, Vilnius Gediminas Technical University, Saulètekio al. 11, 10223 Vilnius-40, Lithuania

E-mail: Edmundas.Zavadskas@adm.vtu.lt

2 Department of Construction Economics and Property Management, Vilnius Gediminas Technical University, Sauletekio al. 11, 10223 Vilnius-40, Lithuania

E-mail:Arturas.Kaklauskas@st.vtu.lt; Audrius.Banaitis@st.vtu.lt; Vaidotas.Trinkunas@st.vtu.lt

\begin{abstract}
The significant part of the constructions' value consists of construction materials price. With the aim of using financial resources for the construction effectively, it is very important that well considered and reasonable decisions should be made regarding the selection of construction materials. Most of all construction on-line systems seek to find how to make the most economic construction decisions and essentially these decisions are intended only for economic objectives. Construction alternatives that are under evaluation have to be evaluated not only from the economic position, but also take into consideration qualitative, technical, technological and other characteristics. Additionally, in seeking to facilitate the work of decision-makers, computer technologies are used that operates according to particular models. These models are based on special mathematical methods in order to facilitate decision-making and apply to a certain decision area. In this article, the possibilities of applying methods for popular decision-making are analyzed regarding the selection of construction materials.
\end{abstract}

KEYWORDS: Construction Materials; Innovations; Decision Methods; Decision Support; Internet System

\section{INTRODUCTION}

The significant part of the constructions' value consists of construction materials price. Thus, when selecting construction materials, it is very important that well considered decisions should be made. Selection of necessary construction materials and relevant suppliers as well as booking and delivery terms is very important reasons, which block the process of construction [4].

Despite high costs of construction materials, often an insufficient attention is being paid to the process of construction materials selection [9]. After making the studies on the process of the construction materials management, it was established that an effective process of construction materials management may im- prove work efficiency 6-8\%, increase goods turnover, reduce an amount of materials possessing insufficient quality, diminish the number of both construction materials and participants of the materials management process, improve work of suppliers, decrease the number of personnel, better evaluate discounts depending on quantity purchased, and diminish waste that occur due to changes and delays of the transactions [4, 9].

In order to solve the following tasks and other ones, there were electronic systems for construction materials commerce created in the world. Due to constant change of information technologies possibilities, however, only the part of the opportunities provided by the systems normally is in use. In this article, the prerequisites for the creation of the model of 
e-commerce system for construction materials are analysed. In addition, the model itself is presented as well as the example of its realisation.

\section{THE ANALYSIS OF THE ELECTRONIC COMMERCE SYSTEMS FOR CONSTRUCTION MATERIALS}

At present there are a good few of electronic business systems created for the construction sector in the world. After the analysis of these systems, it is necessary to single out that their levels of integration into electronic business are very different, starting from the simplest ones designed for acquaintance with the systems of enterprise, and going to the end with some large construction materials' databases or systems for intellectual cooperation. The systems of e-business designed for the construction sector are progressively being created in Lithuania as well. However, the possibilities provided by them are at the initial stage of functional integration and innovation.

Internet had become the environment of information and business. It gives great opportunities as well as many problems, the solution of which determines popularity of e-business systems.

One of the root problems is a search of proper information [7]. If we want to purchase a suitable construction material, we can perform search in particular search systems. Selecting one of the most popular search systems Google and referring to phrase Construction materials buy, we can receive about 7000 different Internet addresses. After the huge work is done and all information presented is revised, a customer can choose several suitable systems in order to compare independently both the prices and technical characteristics.

The other problem is a different user environment in the systems [6]. Each e-business system has different user environment, for example, different navigation menu, distinct processes of getting goods into groups, differ- ent mechanisms of information search, etc.

One more problem lies in the reduction of repeated actions in different systems [5]. In order to revise a huge amount of information, often it is necessary to do the same routine actions such as registration, data retrieval, etc.

With the aim to establish a general view displaying construction materials selection in e-commerce systems, the analysis of the main systems of construction materials was carried out. For this analysis, the systems were selected as follows: BARBOUR INDEX PLC [3]; THE MCGRAW-HILL COMPANIES, INC. [13]; THOMAS REGISTER [17]; AEC INFOCENTER [1]; UAB SAULES SPEKTRAS [16].

Following the results of the analysis mentioned above, the conclusion could be drawn stating that the possibilities to look for construction materials in the e-business systems are well realised. If to choose proper construction materials, in many cases it is possible to receive detailed characteristics determining the material itself and its supplier as well. The matter regarding analysis of the results, however, is not solved yet in the systems analysed. Therefore, a potential buyer can face many problems when he needs to choose an optimal variant from several hundreds alternative construction materials, considering various criteria that describe a material. Probably, the best solution should be the usage of an artificial intelligence, which enables to save very much time when making reasonable decisions.

Realisation of an artificial intelligence should be based on human activity when selecting construction materials from the rich list of the alternatives proposed. Further, the solution of this problem is being analysed, both taking into account and evaluating the actions of a person who makes decisions, particular mathematical methods and models as well.

\section{METHODS FOR THE ASSESSMENT OF A CONSTRUCTION MATERIAL'S EFFICIENCY}

A decision-making process is related to the 
selection of construction materials. Different participants of the decision-making process, including owners, consumers, contractors, architects, designers and others may aim at various purposes. Their intentions can be related to economical, technical and aesthetic requirements as well as to comfort and prestige demands. Therefore for the construction material's selection, the methods that should be applied are those are suitable to perform tasks with several functional purposes.

The classification of the methods is fairly miscellaneous. Classification is determined by the large amount of the decision-making methods that could be successfully applied to the different fields of a person's activity. Zavadskas $[19,15]$ carried out research and applied multiple criteria evaluation methods to engineering: the criteria of the game theory (Maximin (Wald), Minimax, Maximax, Savage, Hurwicz,), generalised criteria (additive, multiple, combinative, efficiency function, technique for order preference by similarity to ideal solution), the methods of consecutive optimisation (decision compatibility/concordance, defining priorities and selection of non-dominant versions) and the synthesis methods as well.

Goicoechea [10] analysed the following methods of multiple criteria decision-making: utility function assessment (Keeney); compromise programming (Zeleny); Electre (Roy, Duckstein); surrogate worth trade-off (Haimes); multi-objective Simplex (Yu, Zeleny); method by Zionts, Wallenius; Ariadne (Sage, White); probabilistic trade-off development, Protrade (Goicoechea, Duckstein) and goal programming (Lee, Ignizio).

With the aim of defining the possibilities for the application of different multiple criteria evaluation methods to construction material's selection, the analysis of the methods was carried out. This involved the analysis of Wald, Maximax, Gurvits and Bayes, simple additive weighting, technique for order preference by similarity to an ideal solution, entropy, analytical hierarchy process, MAUT, PROMETHEE, multiple criteria complex pro- portional assessment and other methods.

The decision-making methods (Wald, Maximax, Gurvits, and Bayes) are usually applied under indetermination conditions and can be used in cases when a producer wants to decide what material he will produce and a supplier wants to choose a material to supply, etc. When selecting construction materials from the position of a customer, application of these methods in many cases is impossible or very complicated.

The weakness of a simple additive weighting technique for order preference by similarity to ideal solution and entropy methods lies in their application, when the calculation results do not put across the real efficiency proportion among the estimated alternatives. The importance of criteria is defined with the help of the entropy method and sometimes it does not coincide with its meanings in practice.

We can also point out two main defects of the analytical hierarchy process method. Firstly, the establishment of a new non-dominant alternative may generally cause some uncertainty concerning two alternatives that were set earlier. However, a more tangible problem is motiveless transition to numbers when doing an appropriate measurement. After a careful analysis it is clear, that with the help of this method we can successfully assess alternatives by considering both the quantitative and qualitative criteria. Nevertheless, it takes much time for calculations even when using computer technologies. In the case when there are many alternatives, calculations can become too complicated.

Demanded mutual independence of priorities and the complexity of data processing limit the possibilities while using the MAUT method. A multiple criteria complex assessment method is used for the analysis of both priority and significance of different versions. Significance and priority directly and proportionally depend on the criteria system and criteria meanings as well as the significance size. These details of the principle of method operation are very important when it is necessary to make a de- 
cision regarding selection of construction materials.

After the careful analysis, conclusions had been drawn that the multiple criteria complex assessment method created by Zavadskas and Kaklauskas is the best one for selection of construction materials. Reliability of the method had been determined in other authors' opinions that carried out the analysis and submitted other possibilities for the application of this method [2, 11, 12, 18, 19, 20].

\section{ARCHITECTURE OF CONSTRUCTION MATERIAL'S DECISION SUPPORT SYSTEM}

There have been many different decision support systems created all over the world [14]. All these systems have particular general principles of operation, namely the architecture of the systems, which include the main functions and characteristics and can be presented with the help of a general algorithm from a decision support system [8]. After evaluating the results of decision-making methods' analysis and the general composition principles of a decision support system, the architecture of a construction material's decision support system was presented. The scheme of this system's algorithm is shown in Figure 1.

Information necessary for a construction material's evaluation includes a database and bases of both knowledge and models.

Experts have the possibility of determining criteria and significances while multiple criteria complex assessment method is used for evaluation. To follow these facts, persons who are responsible for decision-making or other persons taking part in the decision-making process can do some corrections.

In order to receive the necessary information, a person who makes a decision will do so with the help of computer technologies and current information. By doing this, reports, prognosis, recommendations and clarifications on a situation can be presented. In addition, a repeated process should be foreseen in the decision support system when considering extra circumstances and when the results have been achieved.

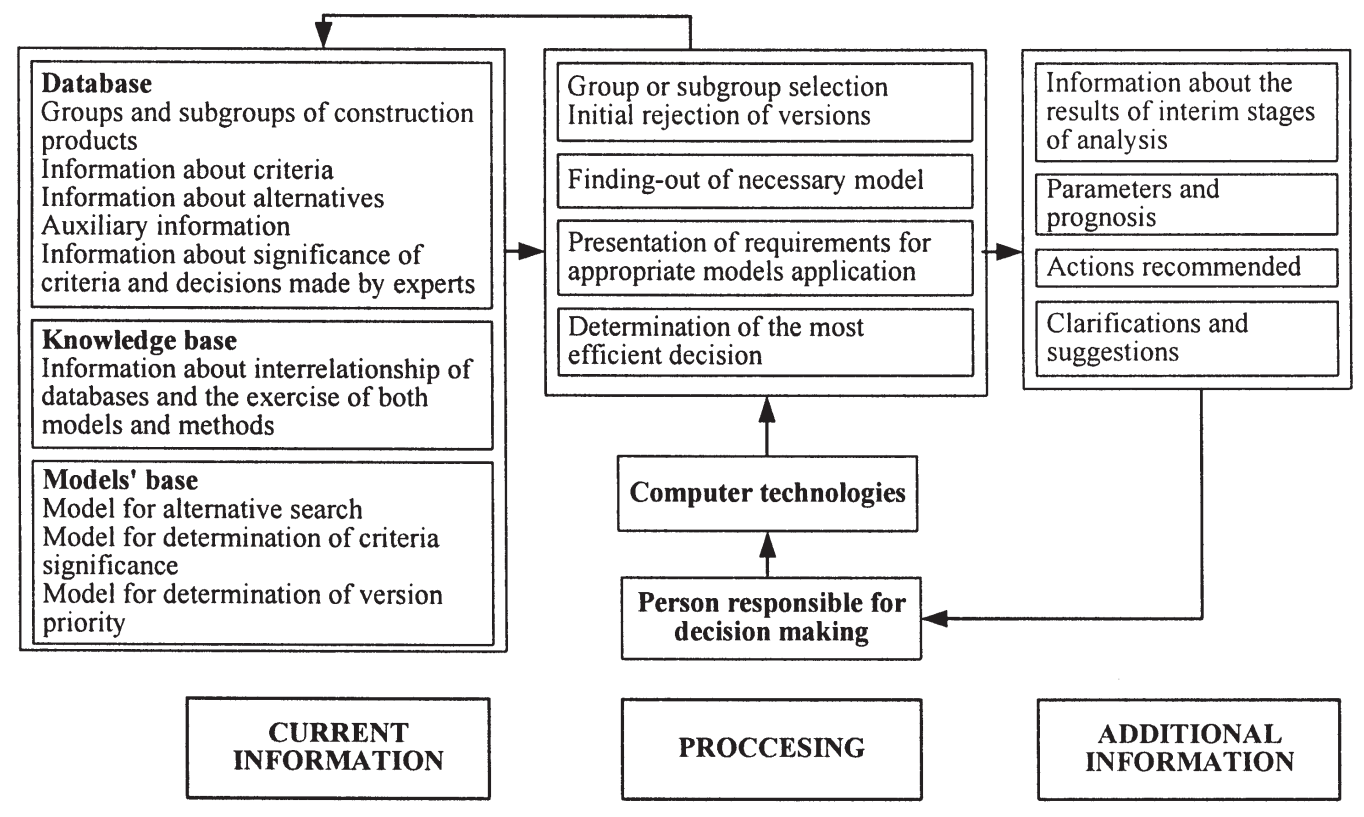

Figure 1. Architecture of a construction material's selection system 


\section{GENERALISED THEORETICAL MODEL OF DECISION-MAKING SUPPORT SYSTEM FOR CONSTRUCTION MATERIALS PURCHASE}

One of the most important conditions allowing good functionality of e-commerce system for construction materials is that the interests of all the participants of the construction process should be evaluated within the system. Therefore, a reasonable mechanism is necessary, which should distinguish particular objectives and functions of different interested groups. The theoretical model of e-commerce system for construction materials is created and presented below in Figure 2.

The system's model presented includes six main parts, such as authorisations of users of the system, database, knowledge base, base of the models, requests and analyses of information, results presentation.

According to the model presented and considering the objectives of users, at the beginning of the work with the system four underlying groups regarding system's users are being identified - sellers, brokers, system administrators as well as buyers. Each of these groups involves the users possessing different

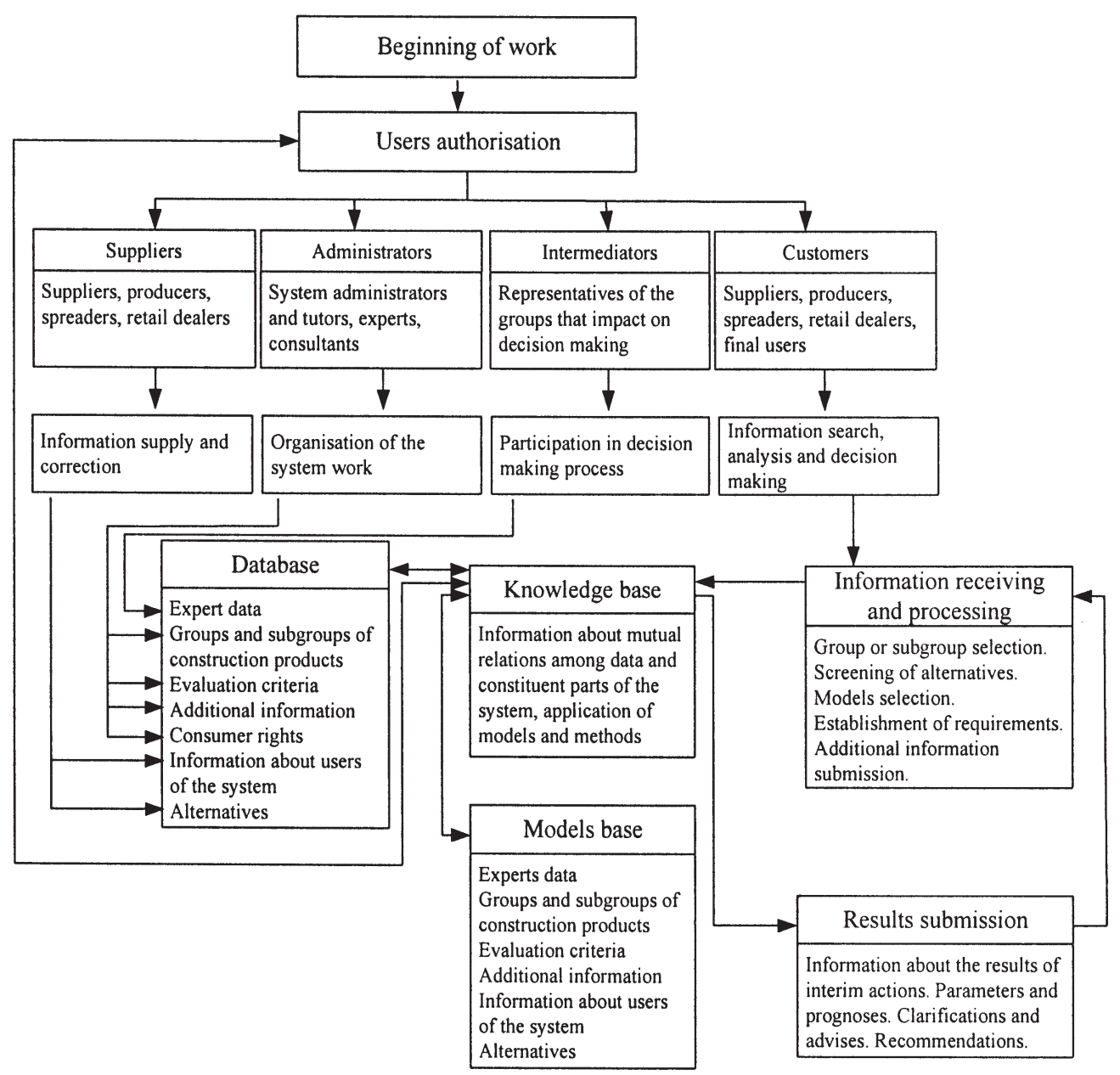

Figure 2. Model of on-line system for construction materials selection 
purposes. For example, persons who express their will to present information about construction materials on sale could be in a position of sellers, and persons who want to receive information about construction materials alternatives proposed could be in a position of buyers, and so on. The groups of users presented may integrate different functions and users having different aims. Besides, these consumers can be divided into subgroups as well, for example, general objective of the group of system administrators lies in organisation of system work so that the system should provide a practical benefit for other users and it should be convenient to use it, etc. However, various participants of this group perform different functions, for instance, the main administrator of the system takes care of technical possibilities of the system while tutors deal with groups and subgroups, select the criteria systems describing alternatives of construction materials, etc.

Rights are established with the help of knowledge base. When applying an artificial intellect, the amount of information provided is limited. Moreover, there remains only what is important in order to implement different aims of users. The role of knowledge does not confine itself strictly to the establishment of rights in the system. There is information saved in the knowledge base, which is designed to perform all intellectual functions of the system. It could be an establishment of mutual relations of information kept in database. Additionally, it also could be succession of models usage, regulation of additional information submission and request. Work of the whole system is organised with the help of this part.

Database carries a very significant weight. Information should be protected so that it should be easily processed and submitted. For this purpose, the main database is divided into the smaller ones, such as information about groups and subgroups, criteria describing construction materials, construction materials alternatives, evaluation of experts, users of the system and others. Various consumers fill the database. This allows to noticeably increasing amount and quality of information, which is in use for decision making to compare with simple Internet sites where one or several users provide data.

The base of models consists of getting goods into the groups, goods selection, significances of criteria, multiple criteria analysis, level of utility, submission of recommendations and models of additional information. They define the succession of the root functions' implementation of e-commerce system for construction materials. The succession of models application, data selection to apply models and submission of the results received during this application depends on the user needs and is regulated in knowledge base.

Additional data necessary for the work of the construction materials system are indicated within information receiving and processing. Information received during this stage is further processed with the help of knowledge base. In the stage of results submission, the information received determines further stages of information processing. If it is necessary, the user can repeat certain stages of information processing.

\section{CASE STUDY}

Residents of a multi-apartment dwelling wanted to change the windows of their apartments. All windows of the apartments are of the same dimensions. A consumer can perform a search for alternatives from different suppliers databases. This is possible since the forms of data submissions are standardized at a specific level. Such standardization creates the conditions for use by special intelligent agents performing a search for the required construction material in various databases, and for gathering information about them. Consumers specify requirements and constraints (see Figure 3) and the OLSC system queries the information of a specific window from a number of online suppliers. Results of the search for specific windows are submitted in tables, which may include direct links to a Web page of sup- 


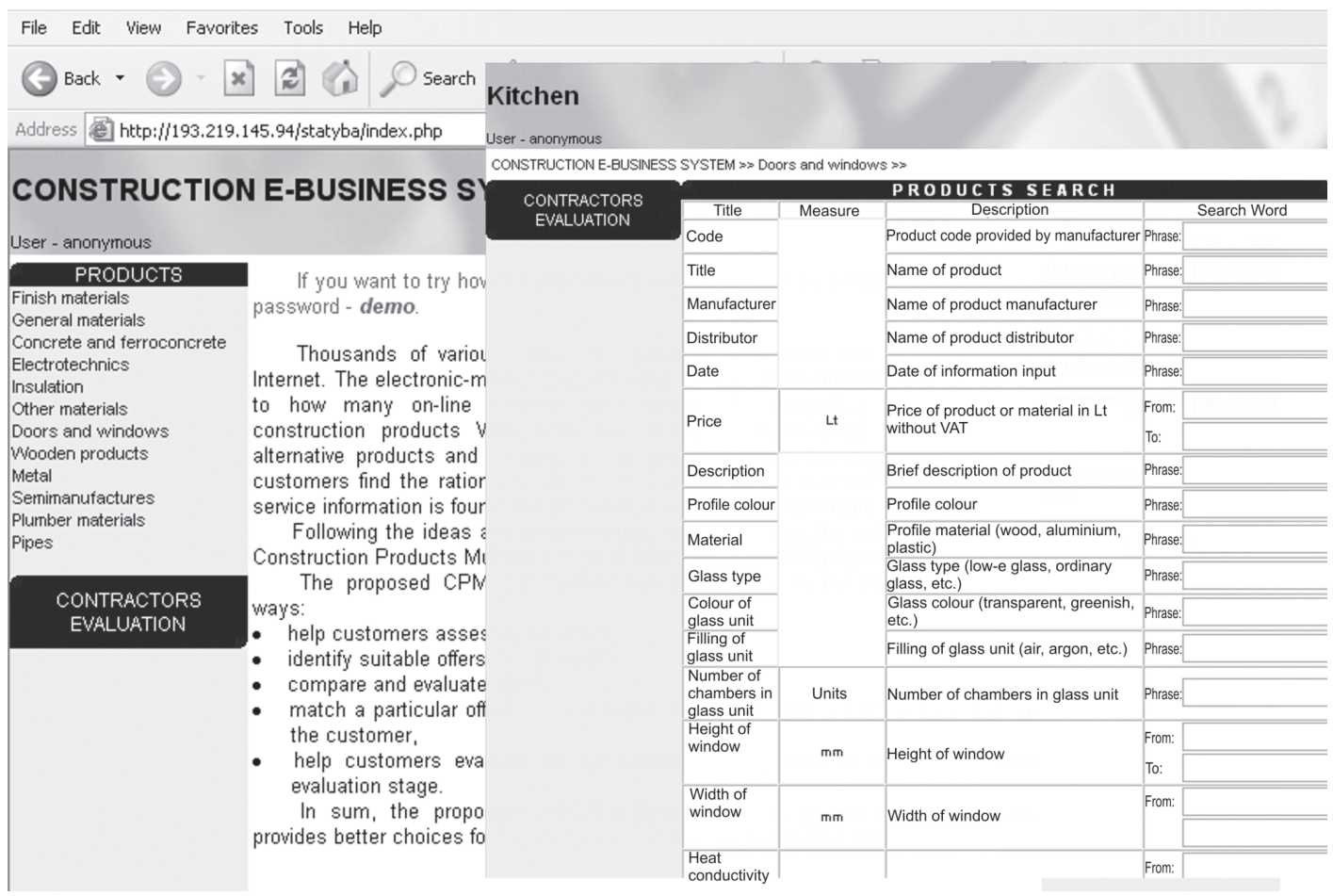

Figure 3. Consumers specify requirements and constraints and the OLSC system queries information of a specific window from a number of online suppliers

pliers. By the submission of such a display, the multiple criteria comparisons can become more effectively supported.

A presentation of information in different types of windows in Web pages can be in conceptual (digital, textual, graphical, photographic, video) form. Conceptual information is needed to make a more complete and accurate valuation of the window alternatives that are being considered. Conceptual description of the first alternative of window is presented in Figure 4.

Residents are interested not only in the price of windows, but in their quality as well. Since the dwelling is near a noisy crossroad, sound insulation of a window became an urgent priority. There is a tendency for regular increases of the price for fuel, and winters are cold in Lithuania and therefore all consumers give greater importance to the thermal insulation of windows. A guarantee period of windows is also important, as are other factors. Five suppliers (Hronas, Doleta, Roda, Alseka, Staliu gaminiai) were found after making a search for the required alternative windows and it was found that they offered 9 alternative windows (see Figure 5).

Decision making matrix formed in the second stage, shows found alternatives. Based on this decision-making matrix it was possible to define the most efficient variant. Each criterion goes together with its measurement unit and weight. The magnitude of weight indicates how many times one criterion is more significant than the other, in a multiple criteria evaluation of window refurbishment. The calculations revealed that the key factors that have affected the efficiency of window refurbishment are: cost (weight $q_{1}=1.0$ ), heat conductivity $\left(\mathrm{q}_{2}=0.54\right)$, sound insulation $\left(\mathrm{q}_{3}=0.21\right)$, guarantee period $\left(\mathrm{q}_{6}=0.12\right)$ and more.

The quantitative information presentation 


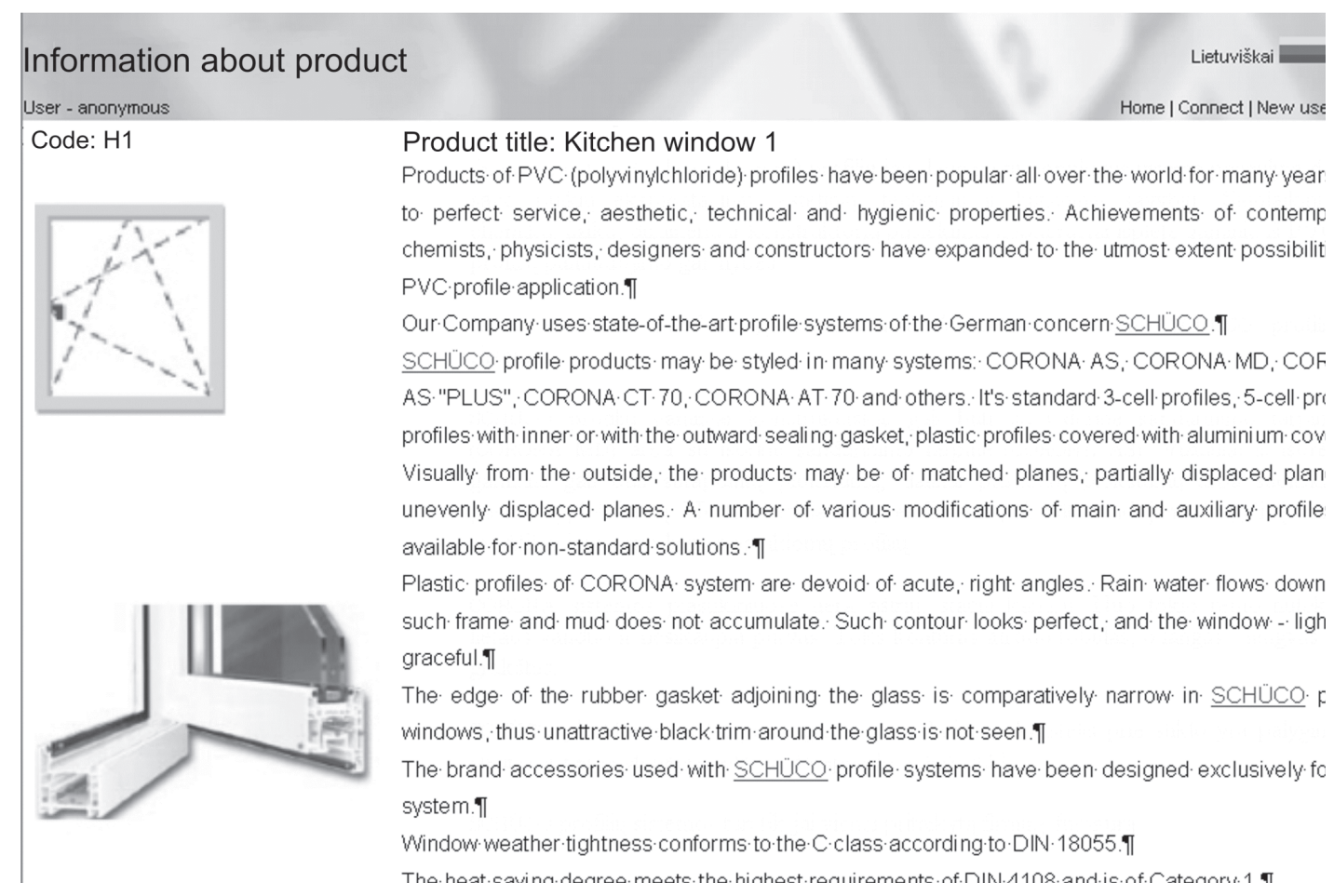

Figure 4. Conceptual description of the first alternative of window

involves criteria systems and subsystems, units of measurement, values and the initial weight, which fully define the provided variants. Quantitative information of windows is submitted in the form of a grouped decision making matrix, where the rows mean $n$ windows under valuation, and columns include quantitative information. In this way, the system enables the decision maker to receive varied conceptual and quantitative information on windows from a database and a model-base, allowing him/her to analyze the above factors and decide on an efficient solution.

Since the analysis of windows is usually performed by taking into account economic, quality, technical, technological, legal, social and other factors, a model-base includes models which enable a decision maker to carry out a comprehensive analysis of the available variants and so make a proper choice.

While going through the purchasing decision process, a customer should examine a large number of alternatives, each of which is surrounded by a considerable amount of information. Following on from the gathered information, the multiple criteria analysis of windows is then carried out (see Figure 6).

\section{CONCLUSIONS}

A potential buyer can face many problems when he needs to choose an optimal variant from several hundreds alternative construction materials, considering various criteria that describe a material. Probably, the best solution should be the usage of an artificial intellect, which enables to save very much time when making reasonable decisions.

After careful analysis of the assessment methods, the conclusions were made that the multiple criteria complex proportional assessment method as created by Zavadskas and Kaklauskas is the best one for a construction material's evaluation. 


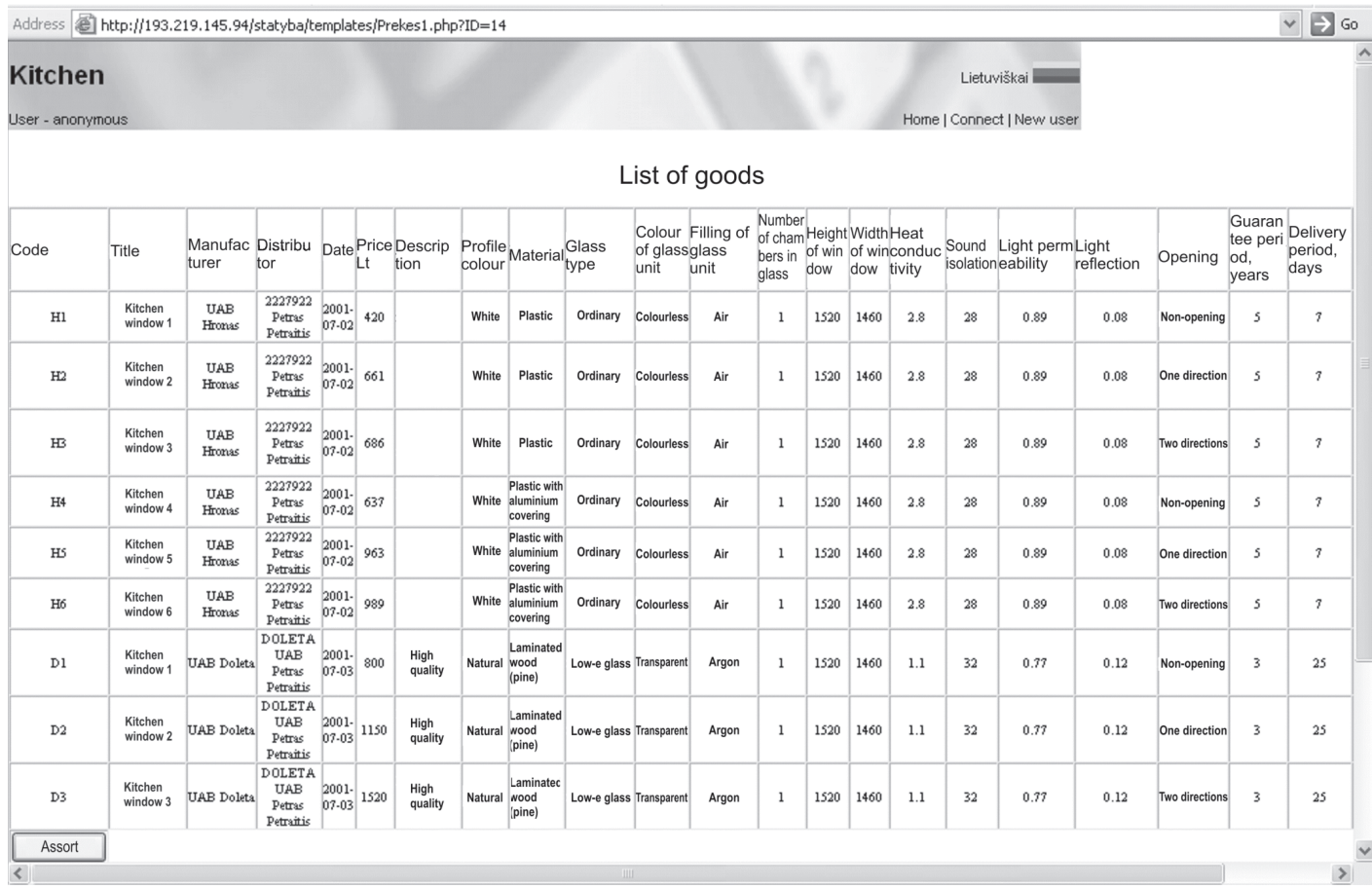

Figure 5. Five suppliers were found after making a search of the required alternative windows

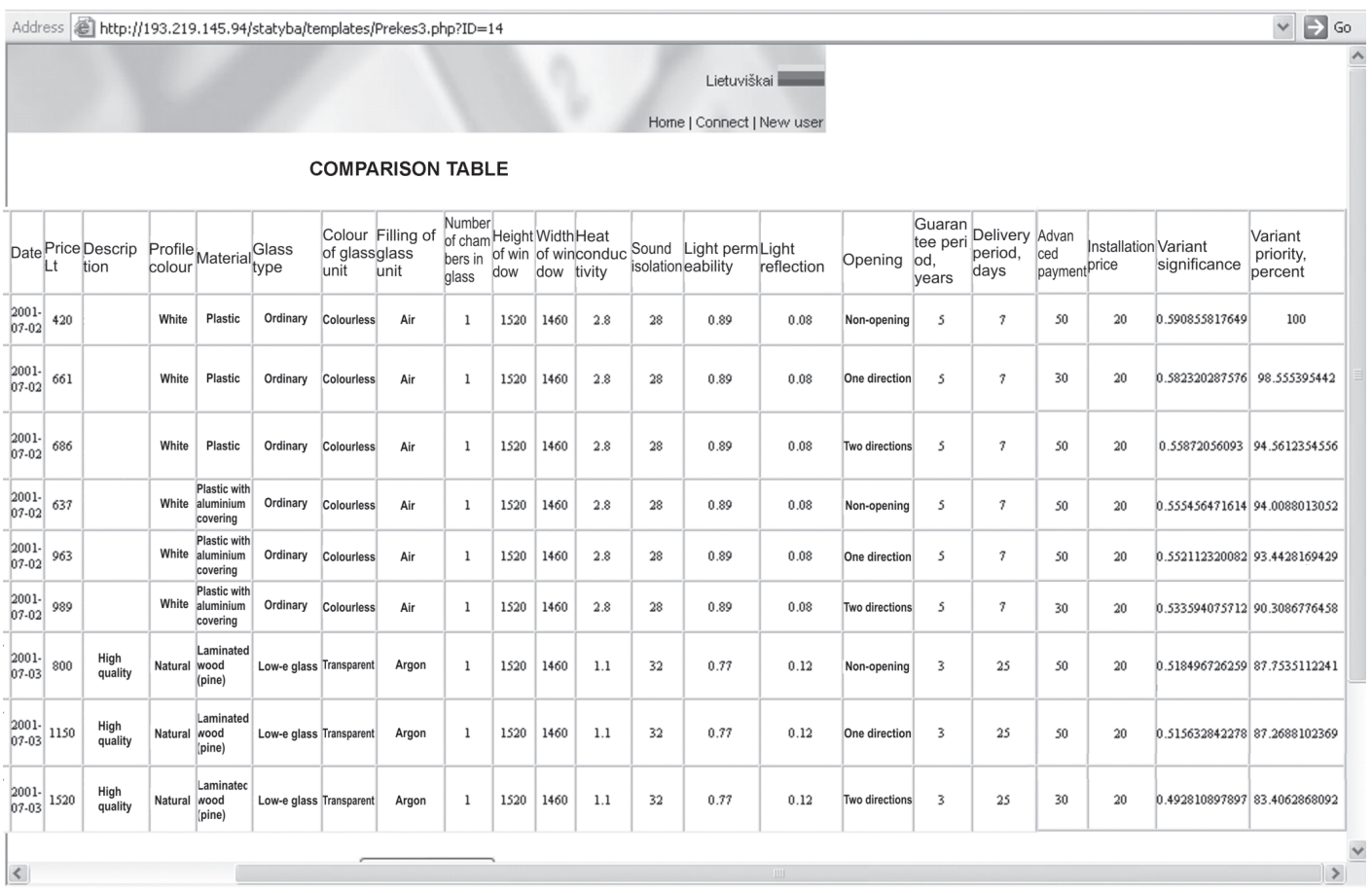

Figure 6. Multiple criteria analysis of window alternatives and the selection of the most efficient ones 
The authors proposed that the realisation of a multiple criteria complex proportional assessment's method could be done according to the algorithm scheme of the construction material's support system.

One of the most important conditions allowing good functionality of e-commerce system for construction materials is that the interests of all the participants of the construction process should be evaluated within the system. In order to realise reasonable mechanism, the theoretical model of construction e-business system is suggested, which could be a basis for creation and improvement of e-commerce systems for construction materials.

\section{Acknowledgement}

This work has been partly funded by the European Commission through IPS Project CONSTRINNONET (Promoting Innovation in Construction Industry SMEs) (No. IPS-200000002). The authors wish to acknowledge the European Commission for their support.

\section{REFERENCES}

[1] AEC INFOCENTER. http://www.aecinfo.com/pdc/ category/category1_1.html [accessed 200305 06]

[2] A. Banaitis, Model of rational housing in Lithuania, Statyba (Civil Engineering), 6(6), 2000, p. 451-456.

[3] BARBOUR INDEX PLC. http:// www.barbourexpert.com/ portal_module/ index.asp [accessed 200204 25]

[4] Construction Research institute, Project Materials Management Handbook, Austin, 1987.

[5] J. Eriksson, N. Finne, S. Janson, Information and interaction in MarketSpace - towards an open agent-based market infrastructure, Second USENIX workshop on Electronic Commerce, 1996.

[6] J. Eriksson, N. Finne, S. Janson, Sics marketspace - an agentbased market infrastructure, In: Agent Mediated Electronic Commerce, P. Noriega and C. Sierra, Eds., no. 1571 in LNAI. Springer Verlag, 1999, p. 41-53.

[7] J. Eriksson, N. Finne, S. Janson, To Each and Everyone an Agent: Augmenting Web-Based
Commerce with Agents, In: Proceedings of the International Workshop on Intelligent Agents on the Internet and Web, Fourth World Congress on Expert Systems, 1998. http:// www.sics.se/ sverker/public/papers/ agentweb.pdf [accessed 200107 05]

[8] G. A. Forgionne, Decision-Making System Effectiveness: the Process to Outcome Link, Information Knowledge Systems Management, 2, 2000, p. 169-188.

[9] C. T. Formoso, V. H. Revelo, Improving the materials supply system in small-sized building firms, Automation in Construction, 8(6), 1999, p. 663-670.

[10] A. Goicoechea, R. W. Nelson, W. Truszkowski, A decision-support system for systems engineering and management, Toward Interactive and Intelligent Decision Support Systems, Vol. 2. Proceedings of the Seventh International Conference on Multiple Criteria Decision Making, 18-22 August 1986, Kyoto, Japan. SpringerVerlag, 1987, p. 71-79.

[11] N. Kvederyte, Analysis of efficiency of singlefamily house life cycle, Statyba (Civil Engineering), 6(6), 2000, p. 445-450.

[12] N. Kvederytė, E. K. Zavadskas, A. Kaklauskas, Multiple criteria analysis of a dwelling life cycle, Statyba (Civil Engineering), 6(3), 2000, p. 179-192.

[13] The McGraw-Hill Companies, Inc. http:// sweets.construction.com/ [accessed 200304 30]

[14] D. Mirchandani, R. Pakath, Four models for a decision support system, Information \& Management, 35(1), 1999, p. 31-42.

[15] F. Peldschus, E. K. Zavadskas, Matrix games in construction and management, Vilnius: Technika, 1997. 134 p. (In Lithuanian).

[16] SAULES SPEKTRAS UAB. http:// www.statyba.lt/ [accessed 200307 28]

[17] THOMAS REGISTER. http:// www.thomasregister.com [accessed 200402 21]

[18] V. Trinkunas, A. Kaklauskas, E. K. Zavadskas, Selection of rational construction products regarding building refurbishments, Property Management, 6(2), 2002, p. 74-82.

[19] E. K. Zavadskas, A. Kaklauskas, Systemotechnical evaluation of buildings, Vilnius: Technika, 1996. 280 p. (In Lithuanian).

[20] E. K. Zavadskas, A. Kaklauskas, A. Banaitis, Analysis, modeling and forecasting of housing credit access, Real Estate Valuation and Investment, 3(2), 1999, p. 101-118. 


\section{SANTRAUKA}

\section{REALAUS LAIKO STATYBINIŲ MEDŽIAGŲ IR GAMINIŲ PARINKIMO SISTEMA}

\section{Edmundas Kazimieras ZAVADSKAS, Artūras KAKLAUSKAS, Audrius BANAITIS, Vaidotas TRINKŪNAS}

Didelę statybų vertès dali sudaro statybinių medžiagų ir gaminių kaina. Norint veiksmingai naudoti statyboms skirtus finansinius išteklius labai svarbu, kad renkantis statybines medžiagas ir gaminius būtų priimami gerai apgalvoti ir pagrịsti sprendimai. Šiuo metu dauguma internetinių elektroninio statybos verslo sistemų priima sprendimus, siejamus su ekonomine nauda ir, savaime suprantama, tam naudojami ekonominę naudą rodantys kriterijai. Tačiau norint priimti gerai pagrisstus sprendimus ekonominių kriterijų nepakanka, taip pat reikia ịvertinti kokybinius, technologinius, techninius ir kitus kriterijus. Siekiant paprastinti sprendimus priimančių žmonių darbą reikia naudoti pagal tam tikrus modelius veikiančias kompiuterines technologijas. Šie modeliai sukurti vadovaujantis specialiais matematiniais metodais. Jie naudojami priimant sprendimus ir pritaikomi tam tikrai sprendimų sričiai. Šiame straipsnyje nagrinėjamos matematinių sprendimo prièmimo metodų taikymo galimybès renkantis statybines medžiagas ir gaminius. 